\title{
The Contributions of U niversity Youth Welfare Departments in Developing the Innovative Thinking Skills of Student Leaders
}

\section{Zainhom Mashhoot Sayed Ahmed Khawaga (PhD)}

\author{
Associate Professor of Social Planning
}

Faculty of Social Work, Helwan University

\section{Ahmed Mohamed Atia Morsy (PhD)}

Assistant Professor, Faculty of Social Work Aswan University 
The Egyptian Journal of Social Work (EJSW) https://ejsw.journals.ekb.eg/e ISSN: 2356-9204 Vol 11, Issue.1, January2021 
The Egyptian Journal of Social Work (EJSW) https://ejsw.journals.ekb.eg/e ISSN: 2356-9204

Vol 11, Issue.1, January2021

\section{ABSTRACT:}

The study aims to identify the contributions of university youth welfare departments in developing the innovative thinking skills of student leaders, which are,(fluency- flexibility - empowerment originality - sensitivity to problems - strategic planning - decision making - team work), and this study belongs to the descriptive studies. The study used the social survey methodology that was used in the random and regular sample of students that are not participating in the student unions at Aswan University in the fourth year of the faculties under study, using the optimum size law of (127) individuals, (75) males, and (52) females. In addition, the study has used the comprehensive social survey methodology among the fourth year student leaders at Aswan University whose number is (128) individuals, (81) males and (47) females. as well as the comprehensive social survey methodology of the officials of Departments of Youth welfare at Aswan University whose number is (46) individuals, each of (26) males and (20) females, of whom (8) work as director of the youth welfare department, (16) activity specialist, and (22) Social worker. The two researchers conducted a questionnaire form of the students that are not participating in student unions, student leaders and officials. The results of the study proved the validity of its hypotheses and its goals that it seeks to achieve.

\section{KEYWORDS:}

University Youth Welfare Departments , Innovative Thinking Skills , Student Leaders.

\section{INTRODUCTION:}

Youth are the centerpiece and the main pillar on which societies depend for achieving development as they are considered a social segment represents a distinct situation in society, where their importance lies in the fact that they are more conscious and aware of the nature of social and cultural interaction prevailing in society, so they must get more attention, care and guidance as they are considered the hope and future of society and the basis on which progress in all areas is built, they are the most dynamic, capable and active groups of the society in the process of change because Because they have innovative energies and capabilities. (Personne, 2005, P 36).

Youth in the Egyptian society form a large segment of the population pyramid, with (18.2\%) of youth in the age group (18-25) years old. This is approximately 18 million people of the population (Central Agency for Public Mobilization and Statistics, 2019, p. 13).

As a result of the increase in the number of youth in the Egyptian 
The Egyptian Journal of Social Work (EJSW) https://ejsw.journals.ekb.eg/e

ISSN: 2356-9204

Vol 11, Issue.1, January2021

society, various institutions have sought to take care of it and develop its innovative ideas in various fields, including universities, as universities include the most important sectors of youth with the best organization, influence and effectiveness . There is no doubt that innovative university students are the human wealth that countries must discover ,release their potentials and invest them , as educational institutions are working to prepare innovative students who are able to solve the problems they face in their lives and who have the ability to think of many and various alternatives to renewable situations (AlMashrafy, 2003, p. 167).

The college youth welfare departments is one of the professional practice fields of social service, which is responsible for providing the means and for planning and implementing professional preventive, developmental and therapeutic programs for students, as well as working to identify the problems and needs of students, prioritize them ,make suitable plans to address these problems, satisfy the needs, and help university youth acquire skills, abilities and trends to help them to be good citizens, and to develop the spirit of innovation among students through practicing various university activities and programs (Ali, Others, 2000, p. 387).

These programs and services are provided by specialists working at the hierarchical structure of youth welfare departments, and the staff in these departments consists of social workers, sports specialists, cultural workers and technicians, in addition to the supervision by some of the staff of the activities of the committees through student families or student unions as presidents of these families or committees (Ali, 1999, p. 27) .

The youth welfare departments operate through committees such as; social, cultural, technical, sports, camps and excursions and provide expertise and services to students through student unions (Suleiman and Al-Afifi, 1993, p. 144).

Student union give students the freedom to think and innovate, discover student leaders and work to give them different experiences and skills, especially innovative thinking skills so that they can face their problems and deal efficiently and effectively with different life situations (Abdul Latif, 2003, p. 126).

Student activities (cultural, artistic, sports, roving, families) work to develop students' innovative thinking skills emotionally, cognitively and cleverly by giving students several skills such as motivation, concentration, self-confidence, independence, material well-being, flexibility, originality, eloquence, sensitivity to problems, social 
The Egyptian Journal of Social Work (EJSW) https://ejsw.journals.ekb.eg/e

ISSN: 2356-9204

Vol 11, Issue.1, January2021

interaction, respect, this requires creating a high quality environment for the development of those skills and this has been proved by the findings of the study(Walsh, 2011) and (Kirkendall \& Anjala 2014 ).

\section{The officials of youth welfare departments work to:}

- Creating a motivating environment for innovative in which the student feels psychologically safe, That is, his ideas and solutions are not threatened by criticism, and help students to be sensitive to problems (cognitive, social and personal), as the first pillar of innovative thinking is sensitivity to problems. This has been proved by the findings of the study (Brouwer, 2019) and (Bin Taleb 2001).

- Developing the flexibility of thinking through the creator's ease of moving from one state of mind to a different one, as if the latter state of thinking was a normal stage in the mental progression of the existing situation, and encouraging students to adopt new ideas and creative solutions, developing the flexibility, independence and originality of thinking, and also introducing students to the methods of developing their creative skills, as the development of creative skills requires going beyond familiar methods of cognition and thinking so it is flexible, and this has been proved by the findings of the study(Abu Al-Nasr, 2018, p. 19) and (Jackson \& Burgess, 2005).

- Developing the skill of fluency by developing the ability of students to generate as many ideas with a situation that requires resorting to the mind to solve or to understand the problem, which is essentially an optional process of remembering and calling information, experiences or concepts already learned to integrate with new experiences to communicate to a new creative performance or produce a quantity of ideas about a particular topic in a fixed time unit . This has been proved by the findings of the study (Samir, 2003).

- Developing the skill of originality of student leaders where originality in thinking is the most related to creativity and is in the sense of novelty and uniqueness and the search in mind for ideas rarely repeated, and these ideas are not subject to common ideas but are distinct, as proved by the findings of the study (Groan, 2002).

- Developing the skill of team work by developing the ability of students to communicate effectively during the practice of student programs and activities, and developing those skills among the student leaders through (trust and positive encouragement by the work team and responding to Student inquiries, willingness to move on new issues, creating an environment that supports creativity) and 


\section{The Egyptian Journal of Social Work (EJSW) https://ejsw.journals.ekb.eg/e}

ISSN: 2356-9204

Vol 11, Issue.1, January2021

this has been proved by the findings of the study (Davis et al , 2012).

- Developing decision-making skills by helping students to think, work together and participate in thinking and decision-making, as empowering the youth by providing them with the opportunity to express their opinions and to participate in decision-making, and giving them leadership skills has led to positive changes in the development of the youth and their integration into social life in society, and this has been proved by the findings of the study (cargo 2003 ).

- Developing communication skills by training students in the right ways of communication, and raising the level of participation in decision-making processes, which reflects on the effectiveness of applying creative methods, where communication allows student leaders to exchange information and ideas on topics related to the practice of creative programs and ideas and this has been proved by the findings of the studies of (Wfry, 2006\& David, 2014).

- Talented student leaders have a leadership personality that helps them communicate with others, make the right decisions and team work, and they are characterized by self-confidence, a love of competition, participation in reform and evaluation, creativity and the ability to find unprecedented solutions in the situations where they are exposed to. This has been proved by the findings of the study (Hart, 2002) and (Milligan, 2004).

- Developing the skill of strategic planning where officials seek to involve students in decisions related to improving the quality of creative programs and activities through prioritization, which supports a sense of belonging and integration of students within the community, as the planner leader is responsible for making and implementing plans and following them up and evaluating them, to have direct results on both the public and private interest and the quality of life of individuals and this has been proved by the findings of the study (Bryan, 2002).

When the officials play the previous roles in developing innovative thinking skills, students acquire leadership skills, as leadership is the behavior a leader practices in order to influence others in order to achieve the desired goals and this has been proved by the findings of the study (Jolly \& Kettler, 2004 ) and (Sternberg, 2005).

There is a relationship between Innovation and leadership where the importance of Innovation for the leaderships lies in the formation of an environment that motivates all workers to grow and improve 
continuously, as the innovative leader has the ability to lead others and accomplish the tasks that others cannot accomplish, and achieve the vision of the future set for the institution by having knowledge and solutions to business problems and inventing new ways of change, and this has been proved by the findings of the study(Jeanie, 2000).

Innovative student leaders also encourage their colleagues to provide innovative solutions and adopt different and innovative methods in their work to satisfy their needs and face their problems while practicing different student activities, as Innovative students need to work under the leadership of people with the same efficiency to enable them to innovate and develop their institutions and this has been proved by the findings of the study (De Pree 2001).

Having Innovative skills helps student leaders to get jobs by reaching out to different segments of policy makers, researchers, practitioners and youth to support their creative potential and increase their ability to work, and this has been proved by the findings of the study (Bamber, 2012) .

Having creative skills by student leaders is also a mechanism for improving the performance and productivity of the institution, consequently, maximizing the social return of developing those skills for individuals, and this has been proved by the study (Kroger, 2011) and (Geoffrey, 2013).

Social planning and community organization are concerned with developing innovative thinking skills among student leaders by designing strategic and tactical plans to develop those skills, and strengthen the contributions of Youth Welfare Departments in implementing those plans. Social planning and community organization are therefore the primary organizational means of designing, implementing and evaluating the innovative thinking skills programs among student leaders to develop competitiveness between youth.

In the light of the above, the study is trying to identifying the contributions of youth welfare departments in developing the innovative thinking skills of student leaders.

\section{Research Importance:}

1. Youth in general, and university youth in particular, are the nation's hope and the capital of any society if they are given sufficient attention and are well prepared to become innovative leaders in the society, especially after the increase in their number to approximately $(18.2 \%)$ percent.

2. The university stage is crucial to the lives of the youth, as positive 
The Egyptian Journal of Social Work (EJSW) https://ejsw.journals.ekb.eg/e

values and trends are crystallized and different skills are developed, especially innovative thinking skills, which are developed through youth welfare departments which have specialists who perform many roles to develop those skills.

3. Developing innovative thinking skills helps student leaders think well about the problems of everyday life and delve deeper into solutions to community issues.

4. The planning process is linked to creative thinking by searching for unique ideas through planning mechanisms and alternatives that lead to the creation of new ideas that work to achieve goals efficiently and effectively.

5. The study deals with the real practice of youth welfare departments and contributions in developing the innovative thinking skills of student leaders.

\section{Research Goals:}

The main goal of the study is : Identifying the contributions of university youth welfare departments in developing the innovative thinking skills of student leaders.

The following sub-goals emerge from this main goal: Identifying the contributions of university youth welfare departments in developing the (fluency, flexibility, empowerment, originality, sensitivity to problems, strategic planning, decision making, team work) skills of student leaders.

\section{- Hypotheses of the study:}

1- The first hypothesis of the study: There are statistically significant differences between the responses of the nonparticipating students and the student leaders regarding their determination of the level of contributions of the youth welfare departments in developing the innovative thinking skills of the student leaders. Testing this hypothesis can be conducted through the following dimensions: Identifying the contributions of university youth welfare departments in developing the (fluency, flexibility, empowerment, originality, sensitivity to problems, strategic planning, decision making, team work) skills of student leaders.

2- The second hypothesis of the study: There are no substantial differences that are statistically significant between the responses of the student leaders and the officials concerning their determination of the level of the contributions of youth welfare departments in developing the innovative thinking skills of student leaders. 
The Egyptian Journal of Social Work (EJSW) https://ejsw.journals.ekb.eg/e

ISSN: 2356-9204

Vol 11, Issue.1, January2021

3- The third hypothesis of the study: There are no substantial differences that are statistically significant between the responses of the student leaders according to the university colleges concerning their determination of the level of the contributions of youth welfare departments in developing the innovative thinking skills of student leaders.

\section{Theoretical Guidelines of the Research:}

The current study is based on several theories including (Hassan, 1997, p. 85):

1. Correlation theory: innovation is a process of organizing the various components of the subject, arranged with each other and re-installing them in an image that corresponds to the need for them in their new form, and the further apart these elements in the arrangement are, the more innovative the result is.

2. Cognitive behavioral approach: It is assumed that human activity or behavior is in fact a problem of forming the relationship between stimuli and responses, knowing that this relationship cannot be used with its observations in the interpretation of innovative behavior and there is no dispute that the individual can implement innovative responses by enhancing his / her opportunity for innovative performance.

3. Theory of Psychoanalysis: This theory makes the innovative process subject to the concept of transcendence or superiority, whereby a person directs his motives to topics of acceptable social value and adapts the motives that lead to otherwise.

4. Gifford's theory of building an innovative mind: Also called the theory of features or factors that are based on the mind, Glyford distinguished characteristics related to innovation on the basis of scientific analysis, namely fluency, originality, flexibility and sensitivity to problems, then rebuilding them. These capabilities are divided into three basic aspects of innovative mental activity they are : a. Receptive appearance: It is the ability to receive stimuli from senses and experiences and this generates sensitivity to problems as a result.

B. Productive appearance: this appears in innovative products that have special characteristics, and here the three capabilities "fluency, flexibility and originality" appear

C. Appraisal Appearance: This appears in the individual's appreciation of what he or she produces or is produced by others, and this measure of appreciation is subjective in the mind of the individual. 
The Egyptian Journal of Social Work (EJSW) https://ejsw.journals.ekb.eg/e

ISSN: 2356-9204

Vol 11, Issue.1, January2021

The justifications for using these theories in the current study are due to identifying the skills of innovative student leaders, and determining the ability of youth welfare departments to achieve their goals currently and expected in the future within the scope of the external environment, and finally, the results of developing innovative thinking skills represented in (originality, flexibility, fluency, sensitivity For problems, strategic planning, decision-making, and teamwork) are considered useful inputs in developing the work of the university's youth welfare departments and improving them in the future, and also contribute to highlighting student leaders who possess these skills and help them develop on the ground to benefit from them in the future.

\section{Concepts:}

\section{(1) Innovative thinking skills:}

There is a difference between creativity and innovation:

Creativity is in performance, as it is a method of targeted and purposeful thinking, through which the individual seeks to discover solutions to his problems in an uncommon way, for every elaborate performance is said to be creativity and we call those who performed this performance "creative" (Saada, 2003, p. 224).

While innovation is linked to getting a head start and the introduction of new things, everyone who finds something before others is innovative, so anyone who came up with an idea that no one has thought of, is an innovator and we say "an innovative idea" (AlGhamdi, 2003, p. 18)

Innovative thinking skills are defined as a set of mental skills that the individual uses to produce new and purposeful ideas, innovative thinking is also a high-quality and distinct human activity that leads to new innovative products and solutions to theoretical or applied problems, in any scientific or life field. These products are characterized by modernity, originality, flexibility and social value (Abdul Rahman, 2004, p. 1).

It is the ability to recognize the deficit in general and choose new hypotheses, to come up with results, or the different ability of thinking based on fluency, flexibility, uniqueness of thinking or originality, sensitivity to problems, and the redefinition and end of existing ideas (Bockers, et al, 2014, p 7).

\section{Innovative thinking skills procedurally mean in this study:}

Fluency skill: It consists in respecting the freedom of each student to think and express his or her opinion, encouraging students to produce as many new innovative ideas as possible, enabling students to use 
The Egyptian Journal of Social Work (EJSW) https://ejsw.journals.ekb.eg/e ISSN: 2356-9204

Vol 11, Issue.1, January2021

known alternatives during activities, helping students call ideas in response to a specific problem or situation, giving each student the chance to make creative proposals for the development of the youth welfare departments.

Flexibility skill: It means the officials are to enable students to overcome all that is typical and expected in the field of youth welfare, help students to understand the variables of the situations they are exposed to, provide multiple options to solve the problems of students, take into account the flexibility of the regulations when students desire to implement the programs.

Originality skill: It means the officials give students unprecedented ideas about practicing activities in youth welfare programs, develop each student's active imagination in a way that benefits the development of youth care programs, transform students from a tool for implementing regulations into a tool for creating solutions and programs, develop students' innovative ideas that surprise their colleagues and officials, help students to apply modern scientific methods to get new and innovative ideas.

Empowerment skill: It means the officials help students explain any mysterious topic innovative, provide innovative ideas for students to implement in the field of youth welfare, encourage new intellectual additions for students to improve the programs of the youth welfare programs , provide many proposed solutions to any problem faced by students while implementing their innovative programs, help students to provide sufficient resources for research and development.

Sensitivity to problems skill: It means the officials are to enable students to know all the exact details of the problems they face during the implementation of programs, give students the skill to choose the right solutions to face their problems at the lowest possible time and cost, help students overcome the difficulties in achieving their goals in the field of youth care, give students sufficient experience and skill to diagnose the problem and know its full dimensions.

Decision-making skill: It means the officials give student leaders the chance to participate in the making, implementation, follow-up and evaluation of decisions related to the development of innovative thinking skills by themselves while providing the required advice if necessary.

Strategic planning skill: It means the officials help student leaders to develop a strategic plan that includes clear goals that are implemented in the least time, effort and cost in the light of the available resources to develop their innovative thinking skills. 
Team work skill: It means a distinct mental activity that leads to new and innovative solutions to face problems in the scientific and life fields, relying on the innovative thinking skills (originality, flexibility, fluency, sensitivity to problems, strategic planning, decision-making, team work) to develop performance now and in the future.

\section{METHODOLOGY:}

This study belongs to the descriptive studies. The study has used the social survey methodology in the random sample for the fourth year students that are not participating in the student unions at Aswan University in the colleges under study using the optimum size law that reached (127) individuals divided into (75) males and (52) females. The study has used the comprehensive social survey methodology of the fourth year student leaders at Aswan University whose number is (128) individuals divided into (81) males and (47) females, this is in light of the statute of student unions of Egyptian universities, as well as the comprehensive social survey methodology of the officials of departments of college youth welfare at Aswan University whose number is (46) individuals divided into (26) males and (20) females, of whom (8) work as directors of the youth welfare department, (16) work as activity specialists, and (22) work as social workers, and they are distributed as follows.

Table (1) Distribution of non-participating students, student leaders and officials at Aswan University Study community

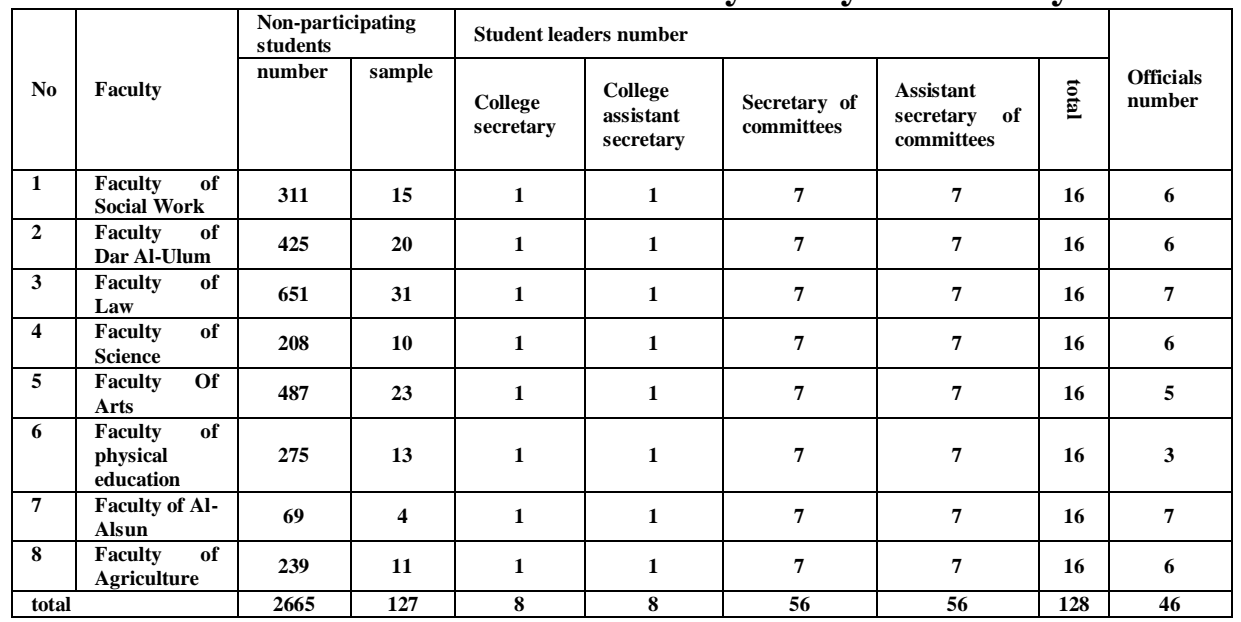

Study tools: The two researchers conducted a questionnaire form of student leaders and officials, The two researchers applied the same form that was applied to student leaders and officials to students that are not participating in student unions, to compare them regarding the contributions of university youth welfare departments in developing 


\begin{tabular}{||cr||}
\hline The Egyptian Journal of Social Work (EJSW) https://ejsw.journals.ekb.eg/e \\
ISSN: $2356-9204$ & Vol 11, Issue.1, January2021 \\
\hline
\end{tabular}

innovative thinking skills, and it was designed electronically as a result of the precautionary measures taken by the state to confront the Corona Virus, where it was sent on the fourth year groups of the colleges under study, by referring to the theoretical heritage, the previous studies and questionnaire forms related to the subject of the study. The dimensions of the questionnaire were identified in nine dimensions, The phrases for each dimension were then identified and formulated, they were(48) phrases, they are distributed as follows:

\section{Table (2) Distribution of questionnaire phrases}

\begin{tabular}{|l|l|l|l|}
\hline No & dimensions & $\begin{array}{l}\text { amount } \\
\text { of } \\
\text { phrases }\end{array}$ & $\begin{array}{l}\text { Number } \\
\text { of } \\
\text { phrases }\end{array}$ \\
\hline 1 & $\begin{array}{l}\text { Identifying the contributions of university youth } \\
\text { welfare departments in developing the fluency skill of } \\
\text { student leaders. }\end{array}$ & 6 & $1-6$ \\
\hline 2 & $\begin{array}{l}\text { Identifying the contributions of university youth } \\
\text { welfare departments in developing the flexibility skill } \\
\text { of student leaders. }\end{array}$ & 6 & $7-12$ \\
\hline 3 & $\begin{array}{l}\text { Identifying the contributions of university youth } \\
\text { welfare departments in developing the empowerment } \\
\text { skill of student leaders. }\end{array}$ & 6 & $13-18$ \\
\hline 5 & $\begin{array}{l}\text { Identifying the contributions of university youth } \\
\text { welfare departments in developing the originality skill } \\
\text { of student leaders. }\end{array}$ & 6 & $25-30$ \\
\hline 5 & $\begin{array}{l}\text { Identifying the contributions of university youth } \\
\text { welfare departments in developing the sensitivity to } \\
\text { problems skill of student leaders. }\end{array}$ & 6 & $31-36$ \\
\hline 6 & $\begin{array}{l}\text { Identifying the contributions of university youth } \\
\text { welfare departments in developing the strategic } \\
\text { planning skill of student leaders. }\end{array}$ & 6 & $37-42$ \\
\hline 7 & $\begin{array}{l}\text { Identifying the contributions of university youth } \\
\text { welfare departments in developing the decision } \\
\text { making skill of student leaders. }\end{array}$ & $\begin{array}{l}\text { Identifying the contributions of university youth } \\
\text { welfare departments in developing the team work skill } \\
\text { of student leaders. }\end{array}$ & 6 \\
\hline
\end{tabular}

- The study was based on the 3 point scale, where the response to each phrase is (yes ,somewhat, no) each response was given a weight (mark): Yes (3 marks),somewhat (2), no (1).

- The two researchers relied on the logical validity through looking at the theoretical literature, and then analyzing it in order to reach the different dimensions associated with the problem of the study.

- Face validity was conducted to the tool after presentation to (5) of the members of the staff of the Faculty of social work University 
The Egyptian Journal of Social Work (EJSW) https://ejsw.journals.ekb.eg/e

ISSN: 2356-9204

Vol 11, Issue.1, January2021

of Helwan, depending on a minimum of agreement rate not less than $(80 \%)$, and the form has been finally phrased.

- A statistical reliability has been done to a sample of (10) persons of student leaders and officials using Cronbach Alpha coefficient and reliability coefficient is (0.89), and it is an appropriate level of statistical reliability.

- The contributions of university youth welfare departments in developing the innovative thinking skills of student leaders is identified as follows:

\section{Table (3) levels of arithmetic averages}

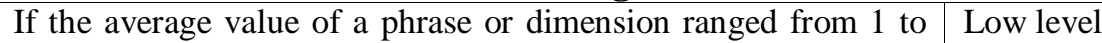
1.67

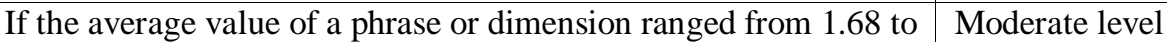
2.34

If the average value of a phrase or dimension ranged from 2.35 to High level 3

\section{- Statistical analysis methods:}

Period of collecting data was from 10/7/2019 to 11/25/2019, and the data have been processed through a computer using program (SPSS. V. 24.0)statistical packages for the social sciences, statistical methods were applied as follows: Frequencies and percentages, arithmetic average, standard deviation,range and Cronbach Alpha reliability coefficient, Independent Two-sample $t$ Test,one-way analysis of variance and the least significant difference test.

\section{- Reasons for comparison between student leaders and officials:}

- Knowing the views of student leaders on the contributions of officials of university youth care departments in developing their innovative thinking skills, and determining whether there is a difference between student leaders regarding the contributions of officials of university youth care departments in developing their innovative thinking skills in different colleges or not?

- Determine the contributions of officials of university youth care departments in developing innovative thinking skills among student leaders, and determine whether there is a difference between the contributions of officials of university youth care departments in developing innovative thinking skills among student leaders in different colleges or not?

\section{- Results of field data:}

Table (4) Moral differences between responses of non-participating students and student leaders regarding their determination of the level of contributions of university youth care departments in developing innovative thinking skills among student leaders $(n=255)$ 


\begin{tabular}{||cr|}
\hline The Egyptian Journal of Social Work (EJSW) https://ejsw.journals.ekb.eg/e \\
ISSN: $2356-9204$ & Vol 11, Issue.1, January2021 \\
\hline \hline
\end{tabular}

\begin{tabular}{|c|c|c|c|c|c|c|c|c|}
\hline No & dimensions & $\begin{array}{l}\text { Research } \\
\text { community }\end{array}$ & number(N) & $\begin{array}{l}\text { Arithmetic } \\
\text { average }\end{array}$ & $\begin{array}{l}\text { Standard } \\
\text { deviation }\end{array}$ & $\begin{array}{l}\text { Degree } \\
\text { of } \\
\text { freedom } \\
\text { (df) }\end{array}$ & $\begin{array}{l}\mathrm{T} \\
\text { value }\end{array}$ & indication \\
\hline \multirow[t]{2}{*}{1} & \multirow{2}{*}{$\begin{array}{l}\text { Fluency skill } \\
\text { development }\end{array}$} & \begin{tabular}{|c|} 
Non- \\
participating \\
students \\
\end{tabular} & 127 & 2.11 & 0.53 & \multirow[t]{2}{*}{253} & \multirow{2}{*}{$-\overline{9} .508$} & \multirow[t]{2}{*}{$* *$} \\
\hline & & student leaders & 128 & 2.65 & 0.36 & & & \\
\hline \multirow[t]{2}{*}{2} & \multirow{2}{*}{$\begin{array}{l}\text { flexibility skill } \\
\text { development }\end{array}$} & $\begin{array}{c}\text { Non- } \\
\text { participating } \\
\text { students }\end{array}$ & 127 & 2.06 & 0.56 & \multirow[t]{2}{*}{253} & \multirow{2}{*}{$-\overline{6}-630$} & \multirow[t]{2}{*}{$* *$} \\
\hline & & student leaders & 128 & 2.47 & 0.41 & & & \\
\hline \multirow[t]{2}{*}{3} & \multirow{2}{*}{$\begin{array}{l}\text { Empowerment } \\
\text { skill } \\
\text { development }\end{array}$} & \begin{tabular}{|c|} 
Non- \\
participating \\
students
\end{tabular} & 127 & 2.1 & 0.57 & \multirow[t]{2}{*}{253} & \multirow[t]{2}{*}{$-\overline{6}$} & \multirow[t]{2}{*}{$* *$} \\
\hline & & student leaders & 128 & 2.49 & 0.34 & & & \\
\hline \multirow[t]{2}{*}{4} & \multirow[t]{2}{*}{$\begin{array}{l}\text { originality skill } \\
\text { development }\end{array}$} & \begin{tabular}{|c|} 
Non- \\
participating \\
students \\
\end{tabular} & 127 & 2.17 & 0.51 & \multirow[t]{2}{*}{253} & \multirow[t]{2}{*}{-} & \multirow[t]{2}{*}{$* *$} \\
\hline & & \begin{tabular}{|l|} 
student leaders \\
\end{tabular} & 128 & 2.44 & 0.37 & & & \\
\hline \multirow[t]{2}{*}{5} & \multirow{2}{*}{$\begin{array}{l}\text { Sensitivity } \text { to } \\
\text { problems skill } \\
\text { development }\end{array}$} & \begin{tabular}{|c|} 
Non- \\
participating \\
students \\
\end{tabular} & 127 & 2.21 & 0.53 & \multirow[t]{2}{*}{253} & \multirow[t]{2}{*}{-} & \multirow[t]{2}{*}{$* *$} \\
\hline & & student leaders & 128 & 2.51 & 0.39 & & & \\
\hline \multirow[t]{2}{*}{6} & \multirow[t]{2}{*}{$\begin{array}{l}\text { Strategic } \\
\text { planning skill } \\
\text { development }\end{array}$} & \begin{tabular}{|c|} 
Non- \\
participating \\
students \\
\end{tabular} & 127 & 2.22 & 0.52 & \multirow[t]{2}{*}{253} & \multirow[t]{2}{*}{-} & \multirow[t]{2}{*}{$* *$} \\
\hline & & student leaders & 128 & 2.42 & 0.49 & & & \\
\hline \multirow[t]{2}{*}{7} & \multirow[t]{2}{*}{$\begin{array}{l}\text { Decision- } \\
\text { making skill } \\
\text { development }\end{array}$} & $\begin{array}{c}\text { Non- } \\
\text { participating } \\
\text { students } \\
\end{array}$ & 127 & 2.17 & 0.5 & \multirow[t]{2}{*}{253} & \multirow[t]{2}{*}{-} & \multirow[t]{2}{*}{$* *$} \\
\hline & & student leaders & 128 & 2.43 & 0.38 & & & \\
\hline 8 & $\begin{array}{l}\text { Team work skill } \\
\text { development }\end{array}$ & \begin{tabular}{|c|} 
Non- \\
participating \\
students \\
\end{tabular} & 127 & 2.08 & 0.57 & 253 & -7.776 & $* *$ \\
\hline & & student leaders & 128 & 2.53 & 0.31 & & & \\
\hline Tota & roles & \begin{tabular}{|c|} 
Non- \\
participating \\
students \\
\end{tabular} & 127 & 2.14 & 0.46 & 253 & $-\overline{7.722}$ & $* *$ \\
\hline & & student leaders & 128 & 2.49 & 0.22 & & & \\
\hline
\end{tabular}

** Significant at (0.01) * significant at $(0.05)$

The previous table shows that: There are statistically significant differences at the level of significance of $(0.01)$ between responses of non-participating students and student leaders with regard to their determination of the level of contributions of youth welfare departments in the development of fluency skill, the development of flexibility skill, the development of proficiency skill, the development of originality skill, the development of the skill of sensitivity to problems, and the development of Strategic planning skill, the development of decision-making skill, the development of team work skill among student leaders, and the contributions of youth welfare departments in developing innovative thinking skills for student leaders as a whole in favor of student leaders' responses. This makes us accept the first hypothesis of the study. 


\begin{tabular}{||cr||}
\hline \multicolumn{1}{|c|}{ The Egyptian Journal of Social Work (EJSW) https://ejsw.journals.ekb.eg/e } \\
ISSN: $2356-9204$ & Vol 11, Issue.1, January2021 \\
\hline
\end{tabular}

Table (5) The significant differences between the responses of the student leaders and the officials concerning their identification of the level of the contributions of university youth welfare departments in developing the innovative thinking skills of student leaders( $\mathrm{N}=174)$

\begin{tabular}{|c|c|c|c|c|c|c|c|c|}
\hline No & dimensions & $\begin{array}{l}\text { Research } \\
\text { community }\end{array}$ & number(N) & $\begin{array}{l}\text { Arithmetic } \\
\text { average }\end{array}$ & $\begin{array}{l}\text { Standard } \\
\text { deviation }\end{array}$ & $\begin{array}{l}\text { Degree } \\
\text { of } \\
\text { freedom } \\
\text { (df) } \\
\end{array}$ & $\begin{array}{l}\mathrm{T} \\
\text { value }\end{array}$ & indication \\
\hline \multirow{2}{*}{1} & \multirow{2}{*}{$\begin{array}{l}\text { Fluency skill } \\
\text { development }\end{array}$} & student leaders & 128 & 2.65 & 0.36 & \multirow{2}{*}{172} & \multirow{2}{*}{1.164} & \multirow{2}{*}{ insignificant } \\
\hline & & The officials & 46 & 2.64 & 0.29 & & & \\
\hline \multirow{2}{*}{2} & \multirow{2}{*}{$\begin{array}{l}\text { flexibility skill } \\
\text { development }\end{array}$} & student leaders & 128 & 2.47 & 0.41 & \multirow{2}{*}{172} & \multirow{2}{*}{1.272} & \multirow{2}{*}{ insignificant } \\
\hline & & The officials & 46 & 2.55 & 0.37 & & & \\
\hline \multirow{2}{*}{3} & \multirow{2}{*}{$\begin{array}{l}\text { Empowerment } \\
\text { skill } \\
\text { development } \\
\end{array}$} & student leaders & 128 & 2.49 & 0.34 & \multirow{2}{*}{172} & \multirow{2}{*}{0.095} & \multirow{2}{*}{ insignificant } \\
\hline & & The officials & 46 & 2.5 & 0.33 & & & \\
\hline \multirow{2}{*}{4} & \multirow{2}{*}{$\begin{array}{l}\text { originality skill } \\
\text { development }\end{array}$} & student leaders & 128 & 2.44 & 0.37 & \multirow{2}{*}{172} & \multirow{2}{*}{1.352} & \multirow{2}{*}{ insignificant } \\
\hline & & The officials & 46 & 2.53 & 0.37 & & & \\
\hline \multirow{2}{*}{5} & \multirow{2}{*}{$\begin{array}{lr}\text { Sensitivity } & \text { to } \\
\text { problems skill } \\
\text { development }\end{array}$} & student leaders & 128 & 2.51 & 0.39 & \multirow{2}{*}{172} & \multirow{2}{*}{0.888} & \multirow{2}{*}{ insignificant } \\
\hline & & The officials & 46 & 2.57 & 0.39 & & & \\
\hline \multirow{2}{*}{6} & \multirow{2}{*}{$\begin{array}{l}\text { Strategic } \\
\text { planning skill } \\
\text { development }\end{array}$} & student leaders & 128 & 2.42 & 0.49 & \multirow{2}{*}{172} & \multirow{2}{*}{1.573} & \multirow{2}{*}{ insignificant } \\
\hline & & The officials & 46 & 2.54 & 0.32 & & & \\
\hline \multirow{2}{*}{7} & \multirow{2}{*}{$\begin{array}{l}\text { Decision- } \\
\text { making skill } \\
\text { development }\end{array}$} & student leaders & 128 & 2.43 & 0.38 & \multirow{2}{*}{172} & \multirow{2}{*}{0.520} & \multirow{2}{*}{ insignificant } \\
\hline & & The officials & 46 & 2.47 & 0.32 & & & \\
\hline 8 & Team work skill & student leaders & 128 & 2.53 & 0.31 & 172 & 0.483 & insignificant \\
\hline 0 & development & The officials & 46 & 2.56 & 0.41 & $1 / 2$ & 0.483 & minsigninicant \\
\hline & & student leaders & 128 & 2.49 & 0.22 & & & \\
\hline Tota & roles & $\begin{array}{l}\text { The } \\
\text { officials }\end{array}$ & 46 & 2.54 & 0.21 & 172 & 1.360 & insignificant \\
\hline
\end{tabular}

The previous table shows that: There are no substantial differences that are statistically significant between the responses of the student leaders and the officials concerning their identification of the level of the total roles of university youth welfare departments in developing the innovative thinking skills of student leaders. This makes us accept the second hypothesis of the study .

Table (6) The significant differences between the responses of the student leaders according to the university faculties concerning their identification of the level of the contributions of university youth welfare departments in developing the innovative thinking skills of student leaders $(N=128)$

\begin{tabular}{|c|c|c|c|c|c|c|c|c|}
\hline No & dimensions & $\begin{array}{l}\text { Source of } \\
\text { Variance }\end{array}$ & $\begin{array}{l}\text { Sum of } \\
\text { squares } \\
\text { (SS) }\end{array}$ & $\begin{array}{l}\text { Degree of } \\
\text { freedom } \\
\text { (df) }\end{array}$ & $\begin{array}{l}\text { Average } \\
\text { of squares }\end{array}$ & $\begin{array}{l}\text { value } \\
\text { F }\end{array}$ & indication & $\begin{array}{l}\text { LSD } \\
\text { test }\end{array}$ \\
\hline \multirow{3}{*}{1} & \multirow{3}{*}{$\begin{array}{l}\begin{array}{l}\text { Fluency skill } \\
\text { development }\end{array}\end{array}$} & $\begin{array}{l}\text { Variance } \\
\text { Between } \\
\text { Groups }\end{array}$ & 2.701 & 7 & 0.386 & \multirow{3}{*}{3.297} & \multirow{3}{*}{$* *$} & \multirow{3}{*}{$\begin{array}{l}6>1 \\
-8\end{array}$} \\
\hline & & $\begin{array}{l}\text { Variance } \\
\text { Within } \\
\text { Groups }\end{array}$ & 14.045 & 120 & \multirow[t]{2}{*}{0.117} & & & \\
\hline & & total & 16.747 & 127 & & & & \\
\hline
\end{tabular}




\begin{tabular}{||cr||}
\hline \multicolumn{2}{|c|}{ The Egyptian Journal of Social Work (EJSW) https://ejsw.journals.ekb.eg/e } \\
ISSN: 2356-9204 & Vol 11, Issue.1, January2021 \\
\hline \hline
\end{tabular}

\begin{tabular}{|c|c|c|c|c|c|c|c|c|}
\hline \multirow{3}{*}{2} & \multirow{3}{*}{$\begin{array}{l}\text { flexibility skill } \\
\text { development }\end{array}$} & $\begin{array}{l}\text { Variance } \\
\text { Between } \\
\text { Groups } \\
\end{array}$ & 4.227 & 7 & 0.604 & \multirow{3}{*}{4.305} & \multirow{3}{*}{ ** } & \multirow{3}{*}{$\begin{array}{l}6>1 \\
-8\end{array}$} \\
\hline & & $\begin{array}{l}\text { Variance } \\
\text { Within } \\
\text { Groups }\end{array}$ & 16.832 & 120 & \multirow[t]{2}{*}{0.140} & & & \\
\hline & & total & 21.059 & 127 & & & & \\
\hline \multirow{3}{*}{3} & \multirow{3}{*}{$\begin{array}{l}\text { Empowerment } \\
\text { skill development }\end{array}$} & $\begin{array}{l}\text { Variance } \\
\text { Between } \\
\text { Groups } \\
\end{array}$ & 1.755 & 7 & 0.251 & \multirow{3}{*}{2.317} & \multirow{3}{*}{ * } & \multirow{3}{*}{$\begin{array}{l}6>1 \\
-8\end{array}$} \\
\hline & & $\begin{array}{l}\text { Variance } \\
\text { Within } \\
\text { Groups }\end{array}$ & 12.984 & 120 & \multirow[t]{2}{*}{0.108} & & & \\
\hline & & total & 14.739 & 127 & & & & \\
\hline \multirow{3}{*}{4} & \multirow{3}{*}{$\begin{array}{l}\text { originality skill } \\
\text { development }\end{array}$} & $\begin{array}{l}\text { Variance } \\
\text { Between } \\
\text { Groups } \\
\end{array}$ & 2.464 & 7 & 0.352 & \multirow{3}{*}{2.898} & \multirow{3}{*}{$* *$} & \multirow{3}{*}{$\begin{array}{l}6>1 \\
-8\end{array}$} \\
\hline & & $\begin{array}{l}\text { Variance } \\
\text { Within } \\
\text { Groups }\end{array}$ & 14.576 & 120 & \multirow[t]{2}{*}{0.121} & & & \\
\hline & & total & 17.041 & 127 & & & & \\
\hline \multirow{3}{*}{5} & \multirow{3}{*}{$\begin{array}{lr}\text { Sensitivity } & \text { to } \\
\text { problems } & \text { skill } \\
\text { development } & \end{array}$} & $\begin{array}{l}\text { Variance } \\
\text { Between } \\
\text { Groups } \\
\end{array}$ & 1.606 & 7 & 0.229 & \multirow{3}{*}{1.546} & \multirow{3}{*}{ insignificant } & \multirow{3}{*}{ - } \\
\hline & & $\begin{array}{l}\text { Variance } \\
\text { Within } \\
\text { Groups }\end{array}$ & 17.8 & 120 & \multirow[t]{2}{*}{0.148} & & & \\
\hline & & total & 19.406 & 127 & & & & \\
\hline \multirow{3}{*}{6} & \multirow{3}{*}{$\begin{array}{l}\text { Strategic } \\
\text { planning skill } \\
\text { development }\end{array}$} & $\begin{array}{l}\text { Variance } \\
\text { Between } \\
\text { Groups } \\
\end{array}$ & 4.694 & 7 & 0.671 & \multirow{3}{*}{3.046} & \multirow{3}{*}{$* *$} & \multirow{3}{*}{$\begin{array}{l}6>1 \\
-8\end{array}$} \\
\hline & & $\begin{array}{l}\text { Variance } \\
\text { Within } \\
\text { Groups } \\
\end{array}$ & 26.417 & 120 & 0.220 & & & \\
\hline & & total & 31.111 & 127 & & & & \\
\hline \multirow{3}{*}{7} & \multirow{3}{*}{$\begin{array}{l}\text { Decision-making } \\
\text { skill development }\end{array}$} & $\begin{array}{l}\text { Variance } \\
\text { Between } \\
\text { Groups } \\
\end{array}$ & 3.680 & 7 & 0.526 & \multirow{3}{*}{4.317} & \multirow{3}{*}{ ** } & \\
\hline & & $\begin{array}{l}\text { Variance } \\
\text { Within } \\
\text { Groups } \\
\end{array}$ & 14.611 & 120 & 0.122 & & & -8 \\
\hline & & total & 18.291 & 127 & & & & \\
\hline & & $\begin{array}{l}\text { Variance } \\
\text { Between } \\
\text { Groups } \\
\end{array}$ & 1.554 & 7 & 0.222 & & & \\
\hline 8 & development & $\begin{array}{l}\text { Variance } \\
\text { Within } \\
\text { Groups } \\
\end{array}$ & 10.470 & 120 & 0.087 & 2.544 & $*$ & $\begin{array}{l}0 \\
-8\end{array}$ \\
\hline & & total & 12.024 & 127 & & & & \\
\hline & & $\begin{array}{l}\text { Variance } \\
\text { Between } \\
\text { Groups } \\
\end{array}$ & 0.580 & 7 & 0.083 & & & \\
\hline & oles & $\begin{array}{l}\text { Variance } \\
\text { Within } \\
\text { Groups } \\
\end{array}$ & 5.804 & 120 & 0.048 & 1.714 & insignificant & - \\
\hline & & total & 6.3843 & 127 & & & & \\
\hline
\end{tabular}

** Significant at (0.01)

* Significant at (0.05)

The previous table shows that :There are substantial differences that are statistically significant at $(0.01)$ and $(0.05)$ between the responses of the student leaders according to the university faculties concerning their identification of the level of the contributions of youth welfare departments in Fluency skill development, Flexibility skill development, Empowerment skill development, Originality skill development, Strategic planning skill development, Decision-making 
skill development, Team work skill development of the student leaders. These differences are in favor of the sixth category, which falls into the (student leadership responses of the Faculty of Physical Education) this makes it the most specific response of student leaders to those dimensions. There are no substantial differences that are statistically significant between the responses of the student leaders according to the university faculties concerning their identification of the level of the contributions of youth welfare departments in Sensitivity to problems skill development of student leaders , and the total contributions of youth welfare departments in developing the innovative thinking skills of student leaders. This makes us accept the third hypothesis of the study.

\section{General Discussion of the Research Issues in Light of the Derived Results:}

The study has proved the validity of its hypotheses and its goals that it seeks to achieve, as it has proved the youth welfare departments have a contribute in developing the innovative thinking skills of student leaders as the officials in these departments work to develop the skill,(originality - flexibility -fluency - sensitivity to problems strategic planning - decision making - team work) of student leaders through the activities and programs the student unions implement. and this has been proved by the findings of the study(Abbie Kirkendall \& Anjala S. Krishen, 2014)، and the study (Brouwer, 2019), and the study (Jackson, Burgess, 2005 )، and the study ( Davis, 2012 ), and the study ( cargo 2003)، and the study ( Bryan , 2002 ). This may reflect the growing interest of youth welfare departments in developing innovative thinking among student leaders, which contributes to the progress of societies, as innovative has become a must to catch up with progress and development in the age of knowledge explosion, which requires ensuring the continuity of program and project planning to develop innovative thinking skills of student leaders to respond to their talents and capabilities in mental excellence, innovative, and special abilities in the various fields of science, arts, literature, leadership and specialized skills.

The findings of the study have also proved that there are no substantial differences that are statistically significant between the responses of the student leaders and the officials concerning their identification of the level of the contributions of youth welfare departments in developing the innovative thinking skills of student leaders where the responses of the individuals of the study sample came close and there may be almost agreement in their responses on 
their identification of the contributions of youth welfare departments in developing the innovative thinking skills ,(originality - flexibility fluency - sensitivity to problems - strategic planning - decision making - team work) of student leaders and this makes us accept the second hypothesis of the study.

The findings of the study have also proved that there are no substantial differences that are statistically significant between the responses of the student leaders according to the university faculties concerning their identification of the level of the contributions of youth welfare departments in developing the innovative thinking skills of student leaders, and this may reflect agreement of the student leaders in the different faculties on the importance of the contributions of youth welfare departments in developing their innovative thinking skills, (originality - flexibility -fluency sensitivity to problems - strategic planning - decision making - team work) and this makes us accept the third hypothesis of the study, accordingly and finally the study has proved with a high level the validity of its goals and its hypotheses that it seeks to achieve .

The findings of the study were also linked to the theories that the researchers relied on to determine the innovative skills of student leaders such as skill (communication, negotiation, strategic planning, decision-making, flexibility, originality, empowerment ..... etc), where the social worker works in student unions as one of the youth welfare departments to develop innovative skills by focusing on the cognitive, value and behavioral basis of skill, as well as the applied aspects, experience and skills to be given to students to become innovative leaders in society. This is through investing in the human element by developing capabilities and preparing technical and administrative cadres, and developing and improving ways and methods of performance by setting systematic and phased plans and programs.

\section{Recommendations of the study:}

Studying efficiency of the indicators of the officials of Youth Welfare Departments and the return on developing the innovative thinking skills of student leaders, studying the problems that face Youth Welfare Departments in developing the innovative thinking skills of student leaders, the necessity of integrating creative thinking skills in the academic content of all educational stages, giving attention to modern teaching and learning methods for developing creative thinking skills, planning programs and projects to develop innovative thinking skills of student leaders, building alliances 
The Egyptian Journal of Social Work (EJSW) https://ejsw.journals.ekb.eg/e

ISSN: 2356-9204

Vol 11, Issue.1, January2021

between Youth Welfare Departments and the surrounding community to develop creative thinking skills.

\section{The study references}

Abdel-Latif , R. A. (2003), Models and Skills of the method of Community Organization in Social Work, Alexandria, The Modern University Office.

Abdel-Rahman, A. M (2004): Skill in Creative Innovative Thinking, Cairo, Higher Institute of Social Work in Cairo.

Abu Al-Nasr, M. Z. (2018): the creativity of practice the black horse in the field of professional rooting, Cairo, the message of fulfillment.

Al-Ghamdi, Ahmed (2003). Innovative thinking, unpublished research, University of Riyadh , Saudi Arabia.

Ali, M. Abu Al-Maati (1999): a proposed conceptual framework for developing university youth care, research published in the Journal of Studies in Social Work and Humanities, sixth edition, Helwan University, Faculty of Social Work.

Ali, M. Abu Al-Maati, and others (2000), General Practice of Social Work in the field of Youth Care, Cairo, Nour Al-Iman Center for Typing and Printing, 2000.

Al-Mashrafi, I. (2003), Effectiveness of a proposed program for developing the competencies of creative thinking education, University Student Magazine, Arab University Council.

Bamber , J. (2012), Developing the creative and innovative potential of young people through non-formal learning in ways that are relevant to employability ,Ireland, Centre, for Effective Services.

Bin Talib, M. (2001), The Impact of Using Brainstorming Strategy in Teaching History on the Development of Creative Thinking for Fourth Level Students in the Sultanate of Oman, Master Thesis, Unpublished, Sultanate of Oman, Sultan Qaboos University, Faculty of Education.

Bockers, Anja \& et, al (2014) : Does Learning in clinical context in anatomical sciences improve examination results, learning motivation or learning orientation? Anatomical sciences education, vol 7 , No 1.

Brouwer, M (2019), Problem Framing Expertise in Public and Social Innovation, She Ji: The Journal of Design, Economics, and Innovation,Volume 5, Issue 1,ISSN 2405 8726,https://doi.org/10.1016/j.sheji.2019.01.003

Bryan , H. (2002), quality of life public planning and private living progressing planning, vol (58), Elsevier science ltd

Cargo , M. (2003), Empowerment as Fostering Positive Youth Development and Citizenship, Canada, University Montreal.

Central Agency for Public Mobilization and Statistics (2019), Yearbook of Statistics, Egypt, Population, Issue 110.

David, D. (2014), Science and Technology Communication for Development, Journal Plos , Biology,2004vol .2 Retrieved, July 11 - 2014 , A Vairable at Ebsco academic Complete search database

De Pree , M.(2001). The creative leadership.No.20.leader to lead.

Garawan, F.A R. (2002), Creativity, Amman, Dar Al-Fikr for Printing and Publishing.

Geoffrey, E. (2013). Character and Impact of Social Innovation in Higher Education. International Journal of Continuing Education and Lifelong Learning. Vol 5 (2)

Hart, L. (2002). Middle School-aged female Interscholastic Soccer Players and Their Academic Achievements, Leadership Position Attachments and Extracurricular 
The Egyptian Journal of Social Work (EJSW) https://ejsw.journals.ekb.eg/e

Club/ Group Participation. Unpublished Master's Thesis, Kean Univ., Union, $\mathrm{NJ}$

Hassan, Mohamed Abdel-Ghani (1997): innovative thinking skills, Cairo, Center for Performance Development and Development.

Jackson. N \& Burgess, H, (2005), Creativity in social work and social work education, Higher Education Academy, October .

Jeanie , G.(2000). Creativity- An essential Component for Effective leadership in todays schools. Vol,22. issue 3 . Roeper Review.

John , M . Davis. Et al (2012), Enabling Creativity in Learning Environments: Lessons From the CREANOVA Project , University of Edinburgh: Learning Landscapes. Autumn.

Jolly, j. \& Kettler, T. (2004). Authentic Assessment of Leadership in ProblemSolving Groups. Gifted Child Today, 27(1), 32-39.

Kirkendall, A \& Anjala S. Krishen (2014), Encouraging Creativity in the Social Work Classroom: Insights from a Qualitative Exploration, Social Work Education, University of Nevada ,USA.

Kroger, P, (2011). Workplace Innovation, Social Innovation, and Social Quality. International Journal of Social Quality. Vol(1) 2, 31-49

Milligan, J. (2004). Leadership Skills of Gifted Students in a Rural: Promising Program for Leadership Development. Rural Special Quarterly, 23.

Mohammed, S. (2003), Effectiveness of a training program for developing innovative thinking skills for tenth grade students in Jordan, Amman, PhD thesis, Amman Arab University.

Personne, L, (2005), Youth and Problem of Change, N,Y, Osaka Publisher.

Saadeh, Jawdat (2003). Teaching thinking skills, Oman, Dar Al Sharq for Publishing and Distribution.

Soliman, A. \& Al-Afifi, A K. (1993), Social Work and School Youth Care, Cairo, Ain Shams Library.

Sternberg, R. J. (2005). WICS: A Model of Giftedness in Leadership: Wisdom, Intelligence, and creativity synthesized. Roeper Review.

Walsh, G, Murphy, P \& et, al (2011), Thinking Skills in the Early Years: A Guide for Practitioners, Stranmillis University College: A college of the queen's University of Belfast.

Wfry, R. (2006). The Relationship between Principals innovative style And teachers perception of Principals Effectiveness, Dissertation Abstract International. 456 (07). 
The Egyptian Journal of Social Work (EJSW) https://ejsw.journals.ekb.eg/e ISSN: 2356-9204 Vol 11, Issue.1, January2021 